\title{
Development and evaluation of diverse promising rapeseed (Brassica napus L.) mutants using physical and chemical mutagens ${ }^{\text {th }}$
}

\author{
Souhail Channaoui ${ }^{1,2}$, Mostapha Labhilili ${ }^{3}$, Mohamed Mouhib ${ }^{4}$, Hamid Mazouz ${ }^{2}$, \\ Mohamed El Fechtali ${ }^{1}$ and Abdelghani Nabloussi ${ }^{1, *}$ \\ ${ }^{1}$ Research Unit of Plant Breeding and Plant Genetic Resources Conservation, National Institute of Agricultural Research, Regional \\ Agricultural Research Center of Meknes, Meknes, Morocco \\ 2 Laboratory of Plant Biotechnology and Molecular Biology, Department of Biology, Faculty of Science, University Moulay Ismail, \\ Meknes, Morocco \\ ${ }^{3}$ Research Unit of Plant Biotechnology, National Institute of Agricultural Research, Regional Agricultural Research Center of Rabat, \\ Rabat, Morocco \\ ${ }^{4}$ Research Unit of Nuclear Techniques, Environment and Quality, Regional Agricultural Research Center of Tangier, Tangier, Morocco
}

Received 5 February 2019 - Accepted 12 July 2019

\begin{abstract}
Genetic variability is a prerequisite for any plant breeding program, and mutagenesis is a proven way of creating new variation within a crop germplasm. Novel genetic variability in rapeseed was induced by gamma rays, Ethyl Methane Sulphonate (EMS) and combined mutagen treatment, using various doses and concentrations. The objective was to evaluate and compare the obtained $\mathrm{M}_{2}$ mutants for important quantitative traits in two contrasted environments. Data on phenological, morphological and agronomic parameters were recorded. A large variability was observed and mutagenic treatments had a significant effect on all traits studied. Compared to control plants, mutant genotypes derived from seeds treated with low EMS concentrations during moderate time were earlier and characterized by a higher number of pods per plant. For high concentration of EMS during long time and for combinations of physical and chemical mutagens, a significant decrease in plant height and stature was noticed, as compared to control. Besides, plants derived from gamma rays-treated seeds exhibited the highest 1000-seed weight. The novel induced variability may be integrated in rapeseed breeding program as a new germplasm with improved agronomic traits. Particularly, EMS1-7-stable mutant may be exploited to develop efficiently and quickly a new rapeseed cultivar with some desirable traits. The present study highlights once more the possibility to bring novel genetic diversity for rapeseed desirable traits improvement through mutation breeding.
\end{abstract}

Keywords: rapeseed / quantitative traits / mutation breeding / EMS treatment / Gamma rays

Résumé - Développement et évaluation de divers mutants prometteurs de colza (Brassica napus $L$.) obtenus par mutagénèse physique et chimique. La variabilité génétique est essentielle pour tout programme d'amélioration de plantes et la mutagénèse s'avère une technique incontestable d'induction de nouvelle variabilité génétique dans les germoplasmes des cultures. Chez le colza, une nouvelle variabilité génétique a été induite après traitement de semences par les rayons gamma, l'EMS et leur combinaison, en utilisant différentes doses et concentrations. L'objectif de cette étude est d'évaluer et comparer les mutants $\mathrm{M}_{2}$ obtenus pour des caractères quantitatifs, dans deux environnements contrastés. Les paramètres étudiés sont d'ordre phénologique, morphologique et agronomique. Une grande variabilité a été observée et les traitements mutagènes ont eu un effet significatif sur tous les paramètres. Les mutants qui proviennent d'une faible concentration d'EMS, durant une période modérée, sont plus précoces et ont un nombre de siliques plus élevé que la variété témoin (non traitée). Par contre, des mutants dérivés de forte concentration d'EMS, pendant une longue période, et de la combinaison d'EMS avec les rayons gamma, ont montré une réduction significative de la hauteur et de la vigueur des plantes. Par ailleurs, les plantes dérivées de

\footnotetext{
H Contribution to the Topical Issue "Rapeseed / Colza"

*Correspondence: abdelghani.nabloussi@gmail.com
} 
semences traitées aux rayons gamma ont eu le poids de 1000 graines le plus élevé. La nouvelle variabilité induite peut être intégrée et utilisée dans le programme de sélection du colza en tant que nouveau germplasm avec des caractéristiques agronomiques améliorées. En particulier, le mutant stable EMS1-7 peut être exploité pour développer efficacement et rapidement un nouveau cultivar de colza ayant des caractéristiques souhaitables. La présente étude indique une fois de plus la possibilité d'apporter une nouvelle diversité génétique pour l'amélioration des caractères d'intérêt du colza à travers la mutagénèse.

Mots clés : colza / caractères quantitatifs / amélioration par mutation / traitement EMS / rayons gamma

\section{Introduction}

Rapeseed (Brassica napus L.), an important oilseed crop, source of vegetable oil and protein-rich meal, is characterized by a substantially increased word production over the last 35 years, which currently reached six times the production recorded in 1980 (Wanasundara et al., 2016). In 2016, the overall production was around 69 million tons (FAOSTAT, 2018). Rapeseed oil is mainly used in human nutrition and biofuel production, whereas rapeseed de-oiled meal is used in animal feed. In general, rapeseed oil contains $\sim 7 \%$ saturated fatty acids (including palmitic acid and stearic acid), and high amounts of monounsaturated fatty acids with a significant fraction of oleic acid $(\sim 61 \%)$. It also contains an important amount of polyunsaturated fatty acids with significant fraction of linoleic acid $(\sim 11 \%)$ and $\alpha$-linolenic acid $(\sim 21 \%)$ (Sharafi et al., 2015).

In Morocco, as well as in other countries of Mediterranean area, rapeseed shows a good adaptation and has a great potential, as a promising oilseed crop that could play a role in improving the vegetable oils production in such countries. Thus, to enhance this production, there is a need to develop and release performant and adapted cultivars.

Available rapeseed germplasm naturally possesses limited genetic variability (Hasan et al., 2006; Bus et al., 2011). Consequently, conventional breeding methods are more and more restrictedly used to release the expected varieties (Tshilenge-Lukanda et al., 2013). The use of mutagenesis to induce novel genetic variability is an effective approach for those crops with narrow genetic base such as rapeseed (Parry et al., 2009). The main advantage of mutation breeding is the possibility of improving one or few characters without changing the rest of the genotype. In recent years, induced mutations have been extensively used for breeding annual oilseed crops (Spasibionek, 2006; Ferrie et al., 2008; Velasco et al., 2008; Emrani et al., 2015; Hussain et al., 2017). Mutagenesis has been also employed to improve a large number of desirable traits like as earliness, dwarfness, biotic and abiotic stress resistance or tolerance, seed yield and oil quality (Schnurbush et al., 2000; Parry et al., 2009; Ali and Shah, 2013; Lee et al., 2018).

Many mutagen agents, either chemical or physical, are available to create and obtain valuable mutations in crop plants. Each particular mutagen agent acts according to a different and specific mode that determines the nature of alteration in plant genetic background (Meinke et al., 1998). However, the biological effect of ionizing radiation like gamma rays depends primarily on the amount of energy that will be absorbed by the biological system for which the chromosomes are the most important target (Van Harten, 1998). Also, Ethyl Methane Sulphonate (EMS) is a chemical mutagen of the alkylating group and has been commonly used in plant breeding because it can cause high frequency of gene mutations and low frequency of chromosome aberration (Van Harten, 1998). Both gamma rays and EMS have been successfully used in rapeseed to evolve new varieties with improved economic traits (Rahman, 1990; Shah et al., 1999).

This study was carried out to compare the relative effectiveness of gamma rays and Ethyl Methane Sulphonate (EMS), applied alone and in combination, for inducing novel genetic variability in rapeseed, to evaluate the developed mutants, for some important traits, and to isolate and select mutants combining some desirable traits. Nevertheless, the study focused only on phenological and agronomic traits non related with seed quality.

\section{Materials and methods}

\subsection{Plant material and treatments applied}

Plant material used in this study was the rapeseed (Brassica napus L.) variety "INRA-CZH2", from the collection of National Institute for Agricultural Research(INRA) of Morocco (Nabloussi, 2015). The physical mutagen (gamma rays) and chemical mutagen (Ethyl Methane Sulphonate, EMS) were applied for mutations induction. Seeds of this variety were subjected to one dose of gamma rays $(1300 \mathrm{~Gy})$, four different concentrations of $\operatorname{EMS}(1,1.2,1.4$ and 1.6\%) during 6,7 and $14 \mathrm{~h}$, and one treatment of these mutagens in combination $(0.8 \%$ EMS during $6 \mathrm{~h}+1100 \mathrm{~Gy})$. Mutagen doses or concentrations used in the present study were designed on the basis of LD50 (lethal dose) results from seed germination test. DL50 is a dose that causes 50\% mortality to the seeds, i.e. a safe dose where $50 \%$ of the seeds can survive. Many researchers think that a dose near to LD50 should be the optimum which varies with crop species and mutagen used (Singh, 2000). Thus, eleven treatment levels were considered in this study: One physical treatment by gamma rays, one combined treatment (EMS + gamma ray) and nine EMS treatments levels as shown in Table 1.

\subsection{Field experiment}

Treated $\left(\mathrm{M}_{1}\right)$ and control $\left(\mathrm{M}_{0}\right)$ seeds were sown on $5 \mathrm{~m}$ long-rows spaced $60 \mathrm{~cm}$ apart, according to a completely randomized design, without replications, on November 2014 at the INRA Experimental Station of Douyet (DYT). This station, at $416 \mathrm{~m}$ above the sea and with an average rainfall of $425 \mathrm{~mm}$ and cracking clay soil, is located at $10 \mathrm{~km}$ form Fez city $\left(34^{\circ} 04^{\prime} \mathrm{N}, 5^{\circ} 07^{\prime} \mathrm{W}\right)$. Climate is of Mediterranean type, with cold and rainy winters, and hot and dry summers. This experimental station is also characterized by a frequent 
Table 1. Concentrations/doses of mutagenic agents used to induce novel genetic variability in rapeseed.

\begin{tabular}{llll}
\hline Mutagen agents & Treatment & & Treatment abbreviation \\
\hline Gamma rays & $1300 \mathrm{~Gy}$ & & 1300 Gy \\
Combined treatment & $1100 \mathrm{~Gy}+0.8 \%$ & Application duration (Hour) & CombT \\
& Concentration (\%) & 6 & - \\
& 1 & 6 & EMS1-6 \\
& 1.2 & 6 & EMS1.2-6 \\
& 1.4 & 6 & EMS1.4-6 \\
EMS & 1.6 & 7 & EMS1.6-6 \\
& 1 & 7 & EMS1-7 \\
& 1.2 & 14 & EMS1.2-7 \\
& 1 & 14 & EMS1-14 \\
& 1.2 & 14 & EMS1.2-14 \\
\hline
\end{tabular}

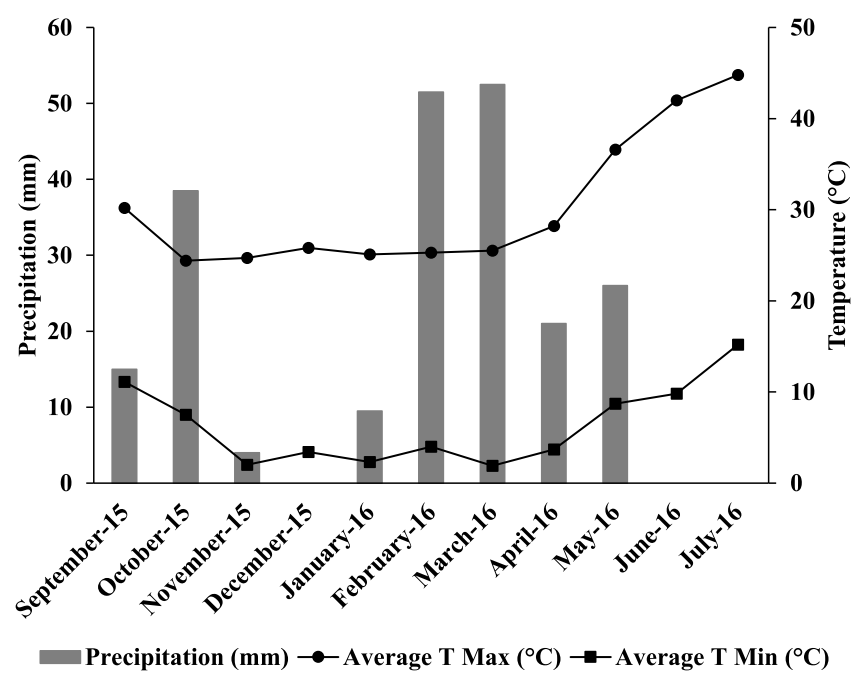

Fig. 1. Average, maximum and minimum monthly temperatures and rainfall recorded in the Experimental Station of Douyet during 2015/ 2016.

presence of the sirocco wind which could be to some extent harmful for crop growing. At flowering, 20 individual $\mathrm{M}_{1}$ plants, from each treatment, and exhibiting interesting attributes, regarding earliness and seed yield related traits, were selected and selfed to produce $\mathrm{M}_{2}$ seeds.

Also, $\mathrm{M}_{2}$ population was planted on 11 November 2015 at DYT and on 20 January 2016 at the INRA Experimental Station of Sidi Alal Tazi (ATZ), as a late sowing date. ATZ is located at $30 \mathrm{~km}$ from Kenitra city $\left(34^{\circ} 31^{\prime} \mathrm{N}, 6^{\circ} \mathrm{W}\right)$, at an elevation of $10.5 \mathrm{~m}$ and with an average annual rainfall of $550 \mathrm{~mm}$. The soil is limestone clay with higher salinity rate than DYT. Figures 1 and 2 show monthly temperatures and rainfall registered in DYT and ATZ, respectively, during the cropping season 2015/2016. In both locations, planting was done in a randomized complete block design on $5 \mathrm{~m}$ long rows spaced by $60 \mathrm{~cm}$. Two rows of the check (untreated original variety seeds) were planted after every 10 rows of treated

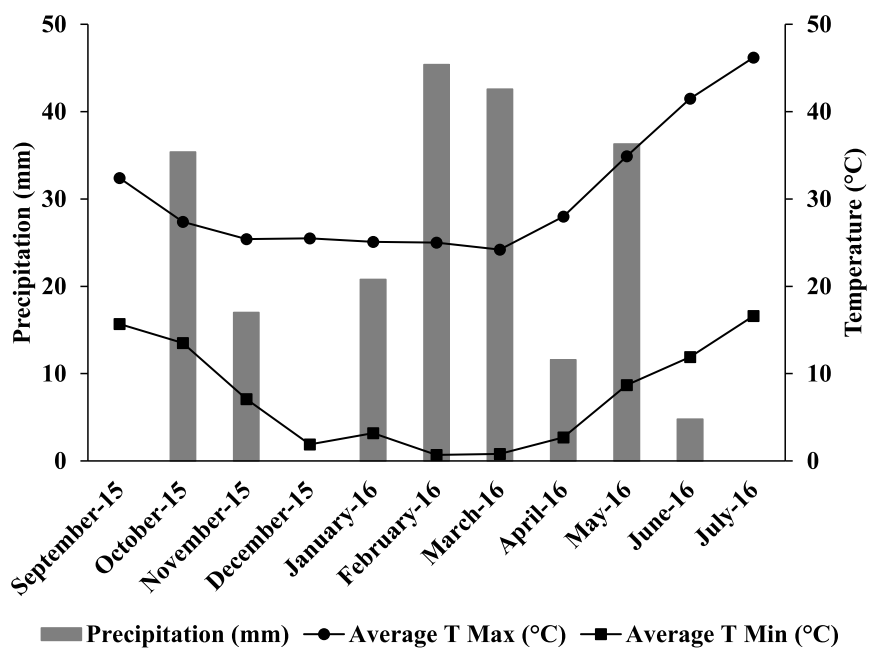

Fig. 2. Average, maximum and minimum monthly temperatures and rainfall recorded in the Experimental Station of Sidi Allal Tazi during 2015/2016.

material to facilitate the comparison during evaluation and selection.

During cropping cycle of $\mathrm{M}_{2}$ population grown in DYT, minimum temperature was $2{ }^{\circ} \mathrm{C}$, recorded on November, while maximum temperature was $44.8^{\circ} \mathrm{C}$, registered on July (Fig. 1). This figure also shows a strong monthly rainfall variation. After planting, and until January, there was no precipitation, so that two irrigations were carried out to ensure a good germination and seedling emergence. Cumulative rainfall was around $218 \mathrm{~mm}$ to which were added the quantities of 20 and $25 \mathrm{~mm}$ brought by both irrigations. The rainiest month was March with about $52 \mathrm{~mm}$ (Fig. 1). On the other hand, at ATZ, minimum $\left(0.7^{\circ} \mathrm{C}\right)$ and maximum $\left(46.2^{\circ} \mathrm{C}\right)$ temperatures were registered on February and July, respectively (Fig. 2). There was a clear monthly rainfall variation, and cumulative rainfall was around $213.9 \mathrm{~mm}$ to which were added the quantity of $30 \mathrm{~mm}$ brought by irrigation in late April to have unstressed 
Table 2. Analysis of variance (mean_squares) for quantitative traits in $\mathrm{M}_{2}$ mutant of Brassica napus L. generated by EMS, gamma rays and their combination (Treatments) and evaluated in two environments (Locations).

\begin{tabular}{|c|c|c|c|c|c|c|c|c|c|c|}
\hline $\begin{array}{l}\text { Source of } \\
\text { variation }\end{array}$ & $\begin{array}{l}\text { Degree of } \\
\text { freedom }\end{array}$ & $\begin{array}{l}\text { Days to } \\
\text { flowering }\end{array}$ & $\begin{array}{l}\text { Days to } \\
\text { maturity }\end{array}$ & $\begin{array}{l}\text { Plant } \\
\text { height }(\mathrm{cm})\end{array}$ & $\begin{array}{l}\text { Number of } \\
\text { branches / } \\
\text { plant }\end{array}$ & $\begin{array}{l}\text { Number of } \\
\text { pods / plant }\end{array}$ & $\begin{array}{l}\text { Number of } \\
\text { seeds / pod }\end{array}$ & $\begin{array}{l}\text { Pod } \\
\text { length }\end{array}$ & $\begin{array}{l}\text { Pod } \\
\text { diameter }\end{array}$ & $\begin{array}{l}\text { 1000-seed } \\
\text { weight }\end{array}$ \\
\hline Location & 1 & $19293.37 * * *$ & $165999.56^{* * *}$ & $72520.2 * * *$ & $582.95^{* * *}$ & $8896092.01 * * *$ & $53.11 *$ & 27.62 & $15.45 * * *$ & $11.49 * * *$ \\
\hline $\begin{array}{l}\text { Treatment } \\
\text { *Location }\end{array}$ & 11 & $87.92 * *$ & $262.06^{* *}$ & 732.68 & 8.05 & $718134.03 * * *$ & $22.46^{*}$ & $84.5^{*}$ & 0.23 & $1.15^{* *}$ \\
\hline
\end{tabular}

$*, * *, * * *$ : Significant at $5 \%, 1 \%$ and $1 \%$ levels, respectively.

11 degrees of freedom because we have 12 overall treatments (11 mutagenic treatments + one check treatment).

flowering conditions. Like DYT, the rainiest month in ATZ was March, with about $45.5 \mathrm{~mm}$. In both experimental stations, the overall water supply (cumulative rainfall and irrigations) remained much lower than average rainfall, indicating that experiment was conducted under relatively dry conditions.

\subsection{Parameters measured}

From each treatment, ten mutant plants, for each mutagenic treatment, were taken randomly to study morphological and agronomic parameters in $\mathrm{M}_{2}$ population. Wild type of the variety "INRA-CZH2" was used as a check. Days to flowering and to maturity of each mutant were calculated as the sum of days from emergence date to date when $50 \%$ of plants of this mutant have flowered and matured, respectively. At maturity, plant height $(\mathrm{cm})$, number of branches per plant and number of pods per plant were determined. After harvest, number of seeds per pod was counted in laboratory. Pod length and diameter ( $\mathrm{mm}$ ) were determined using a caliper whilst 1000-seed weight $(\mathrm{g})$ was determined by a precision balance.

\subsection{Statistical analysis}

Analysis of variance (ANOVA) of gathered data was performed to test significant differences among treatments, environments (sites) and their interaction levels. Duncan's new multiple range test (DMRT) was applied to compare treatment means. Statistical analysis was conducted with the software package SPSS for Windows (Version 22).

\section{Results}

According to results of analysis of variance, mutagen treatment (gamma rays, EMS and their combination) significantly affected the variation of all quantitative traits studied in $\mathrm{M}_{2}$ population (Tab. 2). In addition, there were significant differences between the two INRA Experimental Station of Douyet (DYT) and Sidi Alal Tazi (ATZ) for all parameters with the exception of pod length (Tab. 2). Also, the effect of treatment $\times$ environment interaction was significant on these parameters, except plant height, number of branches per plant and pod diameter (Tab. 2). Therefore, the use of mutagen treatment in rapeseed germplasm, regardless of its type, allowed inducing a novel genetic variability through both environments.
Variation in the parameters measured in $\mathrm{M}_{2}$ progenies, according to the investigated mutagenic treatments is shown in Table 3 for DYT environment, Table 4 for ATZ environment and Table 5 for combined environments. Figure 3 illustrates the novel genetic diversity induced and observed through both experimental environments.

In general, EMS treatments (mainly EMS1-6 and EMS1-7) were found to be more effective for inducing earliness in flowering and maturity, compared to the check and the other mutagenic treatments. In fact, at DYT, mutant lines developed through EMS1-6 and EMS1-7 needed shorter time duration to bloom (99 and 93 days, respectively) and to mature (153 and 171 days, respectively), compared to the check wild variety with 107 and 178 days, respectively (Tab. 3). In ATZ, days to flowering of mutant lines derived form EMS1-6 and EMS1-7 were 76 and 78 days, respectively, and days to maturity were 107 and 106, respectively, whilst the check registered 85 and 111 days, respectively (Tab. 4). Over both locations, it was found that a mutant line derived from EMS1-7 had the lowest average number of days to flowering, 85, and a mutant line coming from EMS1-6 exhibited the lowest average number of days to maturity, 130, compared to 96 and 144 days, respectively, for the check (Tab. 5). On the other hand, seed treatment using $1300 \mathrm{~Gy}$ of gamma rays resulted in a slight and non-significant increase in days to flowering and days to maturity over both locations, while combined treatment, through $1300 \mathrm{~Gy}$ and $0.8 \%$ EMS, induced earliness in flowering and maturity, compared to the check variety (Tab. 5 ). However, the observed earliness was less pronounced than that induced by EMS1-6 and EMS1-7.

Significant variation was observed on plant height for both locations. At DYT, mutants from 1300 Gy treatment and the check variety had the highest plants, with an average of 156.8 and $155.5 \mathrm{~cm}$, respectively, while mutants developed from combined treatment had the shortest ones, with a mean value of $72.5 \mathrm{~cm}$ (Tab. 3). At ATZ, mutant lines coming from $1300 \mathrm{~Gy}$ of gamma rays were characterized by the highest plants, with an average of $125 \mathrm{~cm}$, whilst combined treatment and EMS1.4-14 mutants produced the shortest plants, with a mean value of 72.5 and $73.33 \mathrm{~cm}$, respectively (Tab. 4). For combined locations conditions, mutants developed from 1300 Gy exhibited the highest plants $(141.74 \mathrm{~cm})$, while there was a decrease trend in average plant height with all other EMS treatments. For EMS1.2-6 and EMS1.2-14, plant height was reduced significantly to 112.55 and $111 \mathrm{~cm}$, respectively, as 
Table 3. Effect of different concentrations/doses of chemical mutagen (EMS) and physical mutagen (Gamma rays) and combined mutagen treatment in $\mathrm{M}_{2}$ generation on quantitative traits in rapeseed evaluated in the Experimental Station of Douyet (DYT).

\begin{tabular}{|c|c|c|c|c|c|c|c|c|c|}
\hline Treatments & $\begin{array}{l}\text { Days to } \\
\text { flowering }\end{array}$ & $\begin{array}{l}\text { Days to } \\
\text { maturity }\end{array}$ & $\begin{array}{l}\text { Plant height } \\
(\mathrm{cm})\end{array}$ & $\begin{array}{l}\text { Number of } \\
\text { branches / plant }\end{array}$ & $\begin{array}{l}\text { Number of pods / } \\
\text { plant }\end{array}$ & $\begin{array}{l}\text { Number of } \\
\text { seeds / pod }\end{array}$ & $\begin{array}{l}\text { Pod } \\
\text { length }\end{array}$ & $\begin{array}{l}\text { Pod } \\
\text { diameter }\end{array}$ & $\begin{array}{l}1000 \text {-seed } \\
\text { weight }\end{array}$ \\
\hline Control & $107^{\mathrm{bcd}}$ & $177.6^{\mathrm{ab}}$ & $155.5^{\mathrm{a}}$ & $10.8^{\mathrm{a}}$ & $627.9^{\mathrm{b}}$ & $28.78^{\mathrm{a}}$ & $65.06^{\mathrm{abc}}$ & $4.28^{\mathrm{a}}$ & $2.59^{\mathrm{bc}}$ \\
\hline EMS1-7 & $92.70^{\mathrm{f}}$ & $171.2^{\mathrm{b}}$ & $154.8^{\mathrm{a}}$ & $12.2^{\mathrm{a}}$ & $1504.6^{\mathrm{a}}$ & $27.97^{\mathrm{ab}}$ & $68.8^{\mathrm{a}}$ & $4.25^{\mathrm{ab}}$ & $2.34^{\mathrm{c}}$ \\
\hline EMS1-14 & $115^{\mathrm{a}}$ & $186^{\mathrm{ab}}$ & $127.67^{b}$ & $8.17^{\mathrm{ab}}$ & $496^{\mathrm{b}}$ & $19.22^{d}$ & $52.55^{\mathrm{f}}$ & $3.62^{\mathrm{d}}$ & $1.36^{\mathrm{d}}$ \\
\hline EMS1.2-14 & $112.5^{\mathrm{ab}}$ & $183.8^{\mathrm{ab}}$ & $136^{\mathrm{ab}}$ & $9.8^{\mathrm{a}}$ & $457.7^{\mathrm{b}}$ & $18.99^{\mathrm{d}}$ & $50.88^{\mathrm{f}}$ & $3.79^{\mathrm{bcd}}$ & $2.41^{\mathrm{c}}$ \\
\hline EMS1.4-6 & $110.4^{\mathrm{ab}}$ & $181.6^{\mathrm{ab}}$ & $150.8^{\mathrm{a}}$ & $11^{\mathrm{a}}$ & $772.9^{\mathrm{b}}$ & $23.89^{b c}$ & $60.61^{\text {cde }}$ & $4.13^{\mathrm{abc}}$ & $2.39^{c}$ \\
\hline EMS1.4-14 & $102.71^{\mathrm{cde}}$ & $187^{\mathrm{a}}$ & $140.14^{\mathrm{ab}}$ & $12.14^{\mathrm{a}}$ & $505.29^{b}$ & $19.18^{\mathrm{d}}$ & $52.41^{\mathrm{f}}$ & $3.83^{\mathrm{abcd}}$ & $3.63^{\mathrm{a}}$ \\
\hline EMS1.6-6 & $113.1^{\mathrm{ab}}$ & $185.2^{\mathrm{ab}}$ & $154^{\mathrm{a}}$ & $10.2^{\mathrm{a}}$ & $253.6^{\mathrm{bc}}$ & $21.83^{\mathrm{cd}}$ & $56.38^{\mathrm{def}}$ & $3.95^{\mathrm{abcd}}$ & $2.65^{\mathrm{bc}}$ \\
\hline $1300 \mathrm{~Gy}$ & $112.2^{\mathrm{ab}}$ & $184.7^{\mathrm{ab}}$ & $156.8^{\mathrm{a}}$ & $10.6^{\mathrm{a}}$ & $459.4^{\mathrm{b}}$ & $22.87^{\mathrm{cd}}$ & $61.19^{\text {bcde }}$ & $3.91^{\mathrm{abcd}}$ & $3.24^{\mathrm{ab}}$ \\
\hline
\end{tabular}

Concentrations/doses of treatments used are explained and described in Table 1.

Values with different alphabetical superscripts are significantly different $(p \leq 0.05)$ according to DMRT.

Table 4. Effect of different concentrations/doses of chemical mutagen (EMS) and physical mutagen (Gamma rays) and combined mutagen treatment in $\mathrm{M}_{2}$ generation on quantitative traits in rapeseed evaluated in the Experimental Station of Sidi Allal Tazi (ATZ).

\begin{tabular}{|c|c|c|c|c|c|c|c|c|c|}
\hline Treatments & $\begin{array}{l}\text { Days to } \\
\text { flowering }\end{array}$ & $\begin{array}{l}\text { Days to } \\
\text { maturity }\end{array}$ & $\begin{array}{l}\text { Plant height } \\
(\mathrm{cm})\end{array}$ & $\begin{array}{l}\text { Number of } \\
\text { branches / plant }\end{array}$ & $\begin{array}{l}\text { Number of } \\
\text { pods / plant }\end{array}$ & $\begin{array}{l}\text { Number of } \\
\text { seeds / pod }\end{array}$ & $\begin{array}{l}\text { Pod length } \\
(\mathrm{mm})\end{array}$ & $\begin{array}{l}\text { Pod diameter } \\
(\mathrm{mm})\end{array}$ & $\begin{array}{l}\text { 1000-seed } \\
\text { weight }\end{array}$ \\
\hline Control & $84.6^{\mathrm{ab}}$ & $111^{\mathrm{bcd}}$ & $111.8^{\mathrm{ab}}$ & $5.5^{\mathrm{a}}$ & $191.5^{\mathrm{abc}}$ & $24.35^{\mathrm{ab}}$ & $61.91^{\mathrm{abc}}$ & $3.78^{\mathrm{a}}$ & $1.62^{\text {cde }}$ \\
\hline EMS1-7 & $77.4^{\mathrm{cd}}$ & $105.8^{\mathrm{d}}$ & $92.9^{\mathrm{abc}}$ & $7.1^{\mathrm{a}}$ & $212.4^{\mathrm{a}}$ & $23.31^{\mathrm{abc}}$ & $60.41^{\mathrm{abc}}$ & $3.45^{\mathrm{ab}}$ & $2.45^{\mathrm{abc}}$ \\
\hline EMS1-14 & $89^{\mathrm{a}}$ & $121^{\mathrm{a}}$ & $95^{\mathrm{abc}}$ & $5.33^{\mathrm{a}}$ & $102.33^{\mathrm{bcd}}$ & $22.39^{\mathrm{abc}}$ & $62.89^{\mathrm{ab}}$ & $2.74^{\mathrm{d}}$ & $1.16^{\mathrm{e}}$ \\
\hline EMS1.2-6 & $85.3^{\mathrm{ab}}$ & $115.6^{\mathrm{ab}}$ & $88.6^{\mathrm{bc}}$ & $3.9^{\mathrm{a}}$ & $117.5^{\mathrm{abcd}}$ & $22.77^{\mathrm{abc}}$ & $58.3^{\mathrm{abc}}$ & $3.45^{\mathrm{ab}}$ & $1.62^{\text {cde }}$ \\
\hline EMS1.2-14 & $88.4^{\mathrm{a}}$ & $120^{\mathrm{a}}$ & $86^{\mathrm{bc}}$ & $5.3^{\mathrm{a}}$ & $101.7^{\mathrm{bcd}}$ & $20.1^{\mathrm{cd}}$ & $53.47^{\mathrm{c}}$ & $3.51^{\mathrm{ab}}$ & $1.36^{\mathrm{de}}$ \\
\hline EMS1.4-6 & $84.3^{\mathrm{abc}}$ & $110.8^{\mathrm{bcd}}$ & $113^{\mathrm{ab}}$ & $6.7^{\mathrm{a}}$ & $135.1^{\mathrm{abcd}}$ & $22.34^{\mathrm{abc}}$ & $59.57^{\mathrm{abc}}$ & $3.59^{\mathrm{ab}}$ & $2.15^{\mathrm{abcd}}$ \\
\hline EMS1.4-14 & $84^{\mathrm{abc}}$ & $114^{\mathrm{abc}}$ & $73.33^{\mathrm{c}}$ & $5.33^{\mathrm{a}}$ & $91^{\mathrm{cd}}$ & $17.64^{\mathrm{d}}$ & $42.7^{\mathrm{d}}$ & $2.97^{\mathrm{bc}}$ & $1.55^{\mathrm{cde}}$ \\
\hline EMS1.6-6 & $84.7^{\mathrm{ab}}$ & $115.1^{\mathrm{ab}}$ & $98.7^{\mathrm{abc}}$ & $7.6^{\mathrm{a}}$ & $151.8^{\mathrm{abcd}}$ & $20.3^{\text {bcd }}$ & $57.42^{\mathrm{abc}}$ & $3.6^{\mathrm{ab}}$ & $1.95^{\text {abcde }}$ \\
\hline $1300 \mathrm{~Gy}$ & $84^{\mathrm{abc}}$ & $110^{\mathrm{bcd}}$ & $125^{\mathrm{a}}$ & $7.56^{\mathrm{a}}$ & $186.56^{\mathrm{abcd}}$ & $22.12^{\mathrm{abc}}$ & $59.98^{\mathrm{abc}}$ & $3.34^{\mathrm{abc}}$ & $2.89^{\mathrm{a}}$ \\
\hline
\end{tabular}

Concentrations/doses of treatments used are explained and described in Table 1.

Values with different alphabetical superscripts are significantly different $(p \leq 0.05)$ according to DMRT.

compared to check $(133.65 \mathrm{~cm})$, and for combined treatment, the mutants developed showed the shortest plants, $72.5 \mathrm{~cm}$ (Tab. 5).

At DYT, EMS treatments EMS1-7 and EMS1.4-14 enabled to produce mutants with the most elevated number of branches per plant (12.2 and 12.14, respectively), whereas combined treatment led to mutants with lowest branching (5.5). The check variety had a mean value of 10.8 (Tab. 3). At ATZ, mutants coming from EMS1.6-6 and 1300 Gy produced the highest number of branches per plant (7.6 and 7.56, respectively), whilst mutants derived from EMS1.2-6 and combined treatment showed the lowest branching (3.9 and 4.5, respectively). The check had an average of 5.5 (Tab. 4). In combined environments conditions, the highest average number of branches per plant was 10.10 , observed for EMS1.4-14, followed by 9.65 for EMS1-7 and 9.16 for $1300 \mathrm{~Gy}$. The control had a mean value of 8.15 . Significant decrease in branching was noticed only for the combined treatment, compared to the check (Tab. 5).

In each experimental location, number of pods per plant varied significantly. At DYT, mutants derived from EMS1-7 and EMS1.2-7 produced much higher number of pods per plant (1505 and 1458, respectively) than the check, having an average of 628 pods per plant. On the other hand, combined treatment induced a mutant with the lowest number of pods per plant(112) (Tab. 3). At ATZ, highest number of pods per 
Table 5. Effect of different concentrations/doses of chemical mutagen (EMS) and physical mutagen (Gamma rays) and combined mutagen treatment in $\mathrm{M}_{2}$ generation on quantitative traits in rapeseed evaluated in two different environments (DYT) and (ATZ).

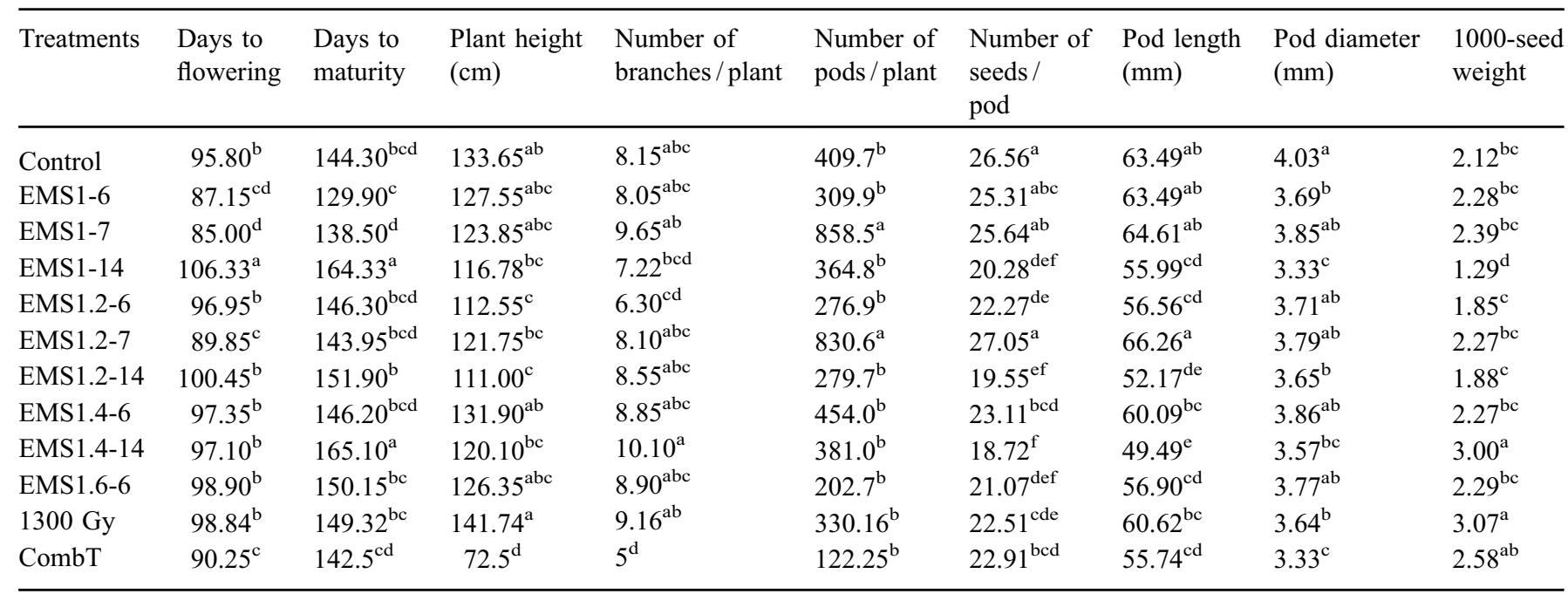

Concentrations/doses of treatments used are explained and described in Table 1.

Values with different alphabetical superscripts are significantly different $(p \leq 0.05)$ according to DMRT.

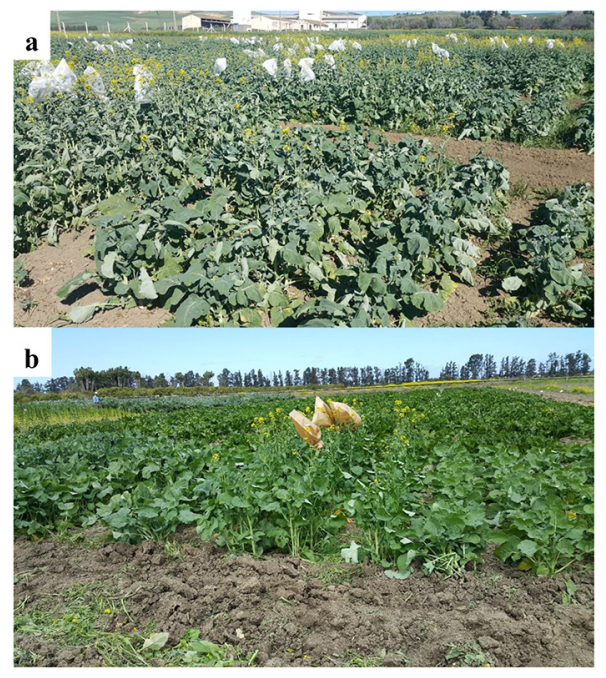

Fig. 3. Novel genetic variability induced by gamma rays and EMS in rapeseed. a: field experiment conducted at Douyet; b: field experiment conducted at Sidi Allal Tazi (2015).

plant(213) was observed in an EMS1-7 mutant, which was significantly higher than that of check (192 pods per plant), whilst the lowest number of pods per plant (83) was found in a mutant developed by combined treatment (Tab. 4). Over both locations, all mutagen treatments affected significantly this trait and, particularly, by applying a treatment of EMS1-7 and EMS1.2-7, a substantial rise in number of pods per plant was observed. In fact, this parameter was 859 and 831 pods in respective mutants, which were more than twice of the check (410 pods). For combined treatment, a mutant with the lowest value (122 pods) was found, when compared to the check and the other mutagenic treatments.

A large variation was noted in number of seeds per pod in both locations. At DYT, the highest mean value was
29.19 seeds/pod, recorded for EMS1.2-7, which remains, however, comparable to the check $(28.78 \mathrm{seeds} / \mathrm{pod})$. The lowest mean value was 18.99 seeds/pod, recorded in EMS1.2-14, followed by 19.18 and 19.22 seeds/pod noticed in EMS1.4-14 and EMS1-14, respectively (Tab. 3). At ATZ, EMS1.4-1 induced a mutant having the lowest number of seeds per pod (17.64), compared to the check (24.35 seeds/pod) (Tab. 4). Over both locations, significant decrease in number of seeds per pod was found for gamma rays-300 Gy and combined treatment (22.51 and $22.91 \mathrm{seeds} /$ pod, respectively), when compared to the check (26.6 seeds/pod). Additionally, our data evidenced high levels of EMS treatment affected negatively and drastically this trait. In fact, by using EMS1.2-14 and EMS1.4-14 treatments, number of seeds per plant was reduced to 19.6 and 18.7 , respectively (Tab. 5).

Pod length and diameter varied significantly according to mutagenic treatments in all studied environments. At DYT, EMS1-7 enabled obtaining the longest pod $(68.8 \mathrm{~mm})$ followed by EMS1.2-7(67.9 mm), whereas EMS1.2-14 and EMS1.4-14 led to the production of mutants characterized by the shortest pods (50.88 and $52.41 \mathrm{~mm}$, respectively). The check variety had a mean value of $65.06 \mathrm{~mm}$ (Tab. 3). At ATZ, the longest pod $(64.62 \mathrm{~mm})$ was observed in EMS1.2-7 mutant, whilst the shortest one $(42.7 \mathrm{~mm})$ was recorded in EMS1.4-14 mutant. The check had an average of $61.91 \mathrm{~mm}$ (Tab. 4). Over both locations, the longest pod, $66.3 \mathrm{~mm}$, was obtained in EMS1.2-7, which was significantly higher than the control average $(63.4 \mathrm{~mm})$, whereas the shortest pod, $49.49 \mathrm{~mm}$, was found in EMS1.4-14 (Tab. 5). Regarding pod diameter, it was negatively affected by all mutagenic treatments, and the lowest value ever observed was $3.3 \mathrm{~mm}$, as a result of EMS1-14 and combined treatments, when compared to $4.03 \mathrm{~mm}$ recorded in the check (Tab. 5).

Regarding 1000-seed weight, significant variation was observed for all mutagenic treatments and over both locations. At DYT, the highest 1000-seed weight was $3.63 \mathrm{~g}$, recorded in EMS1.4-14 treatment, followed by $3.24 \mathrm{~g}$, registered in gamma 
rays-1300 Gy, whilst the lowest one, $1.36 \mathrm{~g}$, was observed for EMS1-14 treatment. The check had a mean value of $2.59 \mathrm{~g}$ (Tab. 3). At ATZ, gamma rays- 1300 Gy treatment induced the highest 1000-seed weight (2.89 g), while EMS1-14 mutant had the lowest one $(1.16 \mathrm{~g})$. The check wild variety had an average of $1.62 \mathrm{~g}$ (Tab. 4). In combined location conditions, gamma rays-1300 Gy and EMS1.4-14 treatments enabled to get mutants with highest 1000-seed weight, namely 3.07 and $3 \mathrm{~g}$, respectively, compared to the check $(2.12 \mathrm{~g})$ and all other treatments applied in this study (Tab. 5).

\section{Discussion}

Like as previous findings (Siddiqui et al., 2009; Emrani et al., 2012; More and Malode, 2016), our results confirmed that gamma rays, Ethyl Methane Sulphonate (EMS) and combination of both were efficient mutagenic treatments for increasing genetic variability in rapeseed quantitative traits. It is common approach in various plant breeding programs to use either physical mutagenesis, particularly through gamma radiation, or chemical mutagenesis, mainly by EMS treatment, as a tool to increase and induce novel genetic variability in germplasms. Usefulness of such mutagen treatments is assessed by their mutagenic effectiveness and efficiency (Begum and Dasgupta, 2010). Chemical mutagens are responsible of DNA base substitution by DNA base alkylation (Cooper et al., 2008), whilst ionizing radiation could cause oxidative damage like base modifications and single or double strand breaks (Roldan-Arjona and Ariza, 2009).

In our investigation, mutants derived from low EMS concentrations and short application duration were earlier to flowering and maturity than the original variety. Application of EMS1-6 and EMS1-7 induced earliness in flowering in $\mathrm{M}_{2}$ mutants, by reducing days to flowering by $9.38 \%$ and $11.45 \%$, respectively, compared to wild type. In previous study, Thurling and Depittayanan (1992) found one $\mathrm{M}_{3}$ rapeseed mutant derived from seeds treated with $0.75 \%$ EMS during $12 \mathrm{~h}$ that flowered 20 days earlier than the parental line. Also, Emrani et al. (2012) had found 6 days earliness in flowering time of $\mathrm{M}_{3}$ lines induced by gamma radiation-1200 Gy treatment. Also, when compared to the wild type, application of EMS1-6 and EMS1-7 induced 14 and 6 days earliness in maturity, respectively, in $\mathrm{M}_{2}$ mutants. In other words, there is in these mutants a genetic gain in terms of maturity earliness of 9.73 and $4.17 \%$, respectively. In Brassica juncea, characterized by much longer crop cycle than $B$. napus, Barve et al. (2009) found one mutant derived from seeds treated with $0.02 \%$ EMS during $3 \mathrm{~h}$, with 47 days earliness in maturity compared to the check, which indicated a cycle reduction of $33.57 \%$. Early flowering provides sufficient time for seed filling, which could result in better seed yield under shortseason and lower rainfall environments. Furthermore, modification of Brassica species flowering time is very relevant in agriculture since it may allow extending the geographical range of these crops (Rae et al., 1999). Induction of maturity earliness is one of the traits most frequently altered in mutation breeding programs in Brassica crops (Kharkwal et al., 2004), and many early mutants have been developed (Rahman et al., 1992; Das et al., 1999; Barve et al., 2009; Malek and Monshi, 2009). In the present study, compared to wild variety and mutants coming from the other mutagenic treatments, mutants derived from EMS1-7 were earlier to flowering and maturity, and were also characterized by a higher number of pods per plant through mutation generations and in both environments. According to obtained data over both experimental locations and to the plant architecture of EMS1-7, we would expect more stability and adaptability of this mutant over various and contrasted environments. In addition, this mutant was generally more adapted than check and other mutants to stressful environments associated with low rainfall, high temperature and contrasted sowing dates. In fact, experimental conditions in both environments were characterized by high maximum average temperatures during March-April period coinciding with flowering and early seed filling (Figs. 1 and 2). Therefore, one could expect that early flowering mutant would be more performant in terms of seed yield and seed oil content under such conditions.

As a result of using high concentration of EMS during long time and combination of physical and chemical mutagens, a significant decrease in plant height and stature was noticed, as compared to control. In a previous study, Kumar and Yadav (2010) had also reported that plant height was found to be significantly reduced by high doses of mutagenic treatment, and in some cases, plants responded positively to lower mutagen doses and recorded a slight increase in their height. Dwarfism in mutant plants can be explained by decline of mitotic activity of meristematic tissues and reduction in moisture content in seeds (Khalil et al., 1986). Improvement in seed yield may be associated with reduction in plant height (More and Malode, 2016), and one could remember that use of dwarfing genes was a key factor in the success of green revolution (Khush, 2001). Dwarfing genes may improve seed yield through reduced lodging and increasing harvest index. Many mutation breeders did isolate dwarf mutants in rapeseed and mustard using physical and chemical mutagenesis (Chauhan and Kumar, 1986; Rai and Singh, 1993; Shah et al., 1999; Javed et al., 2003; Zeng et al., 2011; Wei et al., 2018). On the other hand, an increase in plant height was observed as a result of seed irradiation with gamma rays$1300 \mathrm{~Gy}$. This is in perfect agreement with findings of Emrani et al. (2012) who reported the increase in this trait in $\mathrm{M}_{2}$ and $\mathrm{M}_{3}$ generation mutants induced by gamma rays ionizing.

In the same way, an increase of 1000-weight was observed in mutant plants derived from seeds treated by gamma rays1300 Gy. Similar results were reported by Siddiqui et al. (2009) having used $1000 \mathrm{~Gy}$ of gamma rays to ionize their rapeseed seeds. Also, mutants in oilseed Brassica with improved seed size were obtained using gamma rays in other studies (Chauhan and Kumar 1986; Shah et al., 1990). In our work, one could observe that overall 1000-seedweight, regardless of the mutagenic treatments, was lower than standard and common value which is about $3.50-4.00 \mathrm{~g}$ (Nabloussi, 2015). This was likely due to unfavorable environmental conditions under which the experiment was conducted, particularly characterized by drought and heat stress in both experimental environments. In fact, it is well known that seed weight is an important seed yield component that is strongly affected by environmental conditions (Diepenbrock, 2000).

Following the use of gamma rays and EMS mutagens, a novel genetic variability was induced and promising mutants 
were obtained. However, EMS was more interesting as it generated the most performant mutants in terms of flowering earliness and seed yield, mainly when it was applied in low dose and during moderate time. Previous reports had also shown that EMS effectiveness was higher than gamma rays (Thakur and Sethi, 1995; Kharkwal, 1998; Solanki, 2005; Wani, 2009; Begum and Dasgupta, 2010).

However, acquisition of novel desirable mutations has been, recently, facilitated by the introduction of targeted genome editing (GE) technologies, especially clustered regularly interspaced short palindromic repeats (CRISPR)/ (CRISPR)-associated 9(Cas9) (Braatz et al., 2017). The application of CRISPR-Cas9-targeted mutagenesis in plants has been reported not only in Arabidopsis (Fauser et al., 2014; Feng et al., 2014) but also in crops like wheat (Wang et al., 2014), tomato (Brooks et al., 2014), and rice (Li et al., 2016). In rapeseed, some few studies have already presented targeted genome editing mediated by the CRISPR/Cas9 system (Braatz et al., 2017; Okuzaki et al., 2018; Sun et al., 2018). Therefore, as more and more genes are identified for their function, mutagenesis in rapeseed plant breeding could be managed by more efficient ways than chemical/physical and random ways.

\section{Conclusion}

In conclusion, we confirmed that gamma rays, Ethyl Methane Sulphonate(EMS) and combination of both were potent and highly effective for inducing novel variability in some important agronomic traits in rapeseed. Different mutagenic treatments enabled to develop various mutants with modified and desirable characteristics. Interestingly, modifications and particular characteristics of these mutants were recorded at the level of $\mathrm{M}_{1}$ and $\mathrm{M}_{2}$ plants, and were maintained over both environments of this study. This suggested that these mutants were stable and thus, they could be used and exploited efficiently in rapeseed breeding program. Among the various mutagenic treatments used in present investigation, EMS1-7 was found to be more effective in obtaining earliness in flowering and maturity and to increase number of pods per plant, which is the most important component of seed yield. On the other hand, mutants derived from high dose of EMS during long time and from combination treatment of physical and chemical mutagens decreased significantly plant height and, as a result, short statured plants were obtained. Furthermore, plants derived from seeds irradiated by gamma rays-1300 Gy exhibited the highest 1000-seed weight. Overall, the mutants developed in this study will increase the available genetic variability in Moroccan rapeseed germplasm. Many of these mutants might be stable and thus may enable to develop efficiently and quickly new rapeseed cultivars with different desirable traits.

\section{References}

Ali HMA, Shah SA. 2013. Evaluation and selection of rapeseed (Brassica napus L.) mutant lines for yield performance using augmented design. J Anim Plant Sci 23: 1125-1130.

Barve YY, Gupta RK, Bhadauria SS, Thakre RP, Pawar SE. 2009. Induced mutations for development of $B$. juncea canola quality varieties suitable for Indian agro-climatic conditions. In: Induced plant mutations in genomics era. Food and Agriculture Organization of the United States, pp. 373-375.

Begum T, Dasgupta T. 2010. A comparison of the effects of physical and chemical mutagens in sesame (Sesamum indicum L.). Genet Mol Biol 33: 761-766.

Braatz J, Harloff HJ, Mascher M, Stein N, Himmelbach A, Jung C. 2017. CRISPR-Cas9 targeted mutagenesis leads to simultaneous modification of different homoeologous gene copies in polyploid oilseed rape (Brassica napus). Plant Physiol 174(2): 935-942.

Brooks C, Nekrasov V, Lippman ZB, Van Eck J. 2014. Efficient gene editing in tomato in the first generation using the clustered regularly interspaced short palindromic repeats/CRISPR-associated9 system. Plant Physiol 166: 1292-1297.

Bus A, Körber N, Snowdon RJ, Stich B. 2011. Patterns of molecular variation in a species-wide germplasm set of Brassica napus. Theor Appl Genet 123(8): 1413-1423.

Chauhan YS, Kumar K. 1986. Gamma ray induced chocolate seeded mutant in Brassica campestris var. Yellow Sarson. Curr Sci 55: 410.

Cooper JL, Till BJ, Laport RG, et al. 2008. TILLING to detect induced mutations in soybean. BMC Plant Biol 8: 9.

Das ML, Rahman A, Malek MA. 1999. Two early maturing and high yielding varieties of rapeseed developed through induced mutation technique. Bang J Bot 28: 27-33.

Diepenbrock W. 2000. Yield analysis of winter oilseed rape (Brassica napus L.): A review 2000. Field Crops Res 67: 35-47.

Emrani SN, Arzani A, Saeidi G, et al. 2012. Evaluation of induced genetic variability in agronomic traits by gamma irradiation in canola (Brassica napus L.). Pak J Bot 44: 1281-1288.

Emrani SN, Harloff H, Gudi O, Kopisch Obuch F, Jung C. 2015. Reduction in sinapine content in rapeseed (Brassica napus L.) by induced mutations in sinapine biosynthesis genes. Mol Breed 35 (1): 37.

FAOSTAT. 2018. Available from http://www.fao.org/faostat/en/ \#data/ (last consult: 2018/12/04).

Fauser F, Schiml S, Puchta H. 2014. Both CRISPR/Cas-based nucleases and nickases can be used efficiently for genome engineering in Arabidopsis thaliana. Plant J 79: 348-359.

Feng Z, Mao Y, Xu N, et al. 2014. Multigeneration analysis reveals the inheritance, specificity, and patterns of CRISPR/Cas-induced gene modifications in Arabidopsis. Proc Natl Acad Sci USA 111: 4632-4637.

Ferrie AMR, Taylor DC, MacKenzie SL, Rakow G, Raney JP, Keller WA. 2008. Microspore mutagenesis of Brassica species for fatty acid modifications: a preliminary evaluation. Plant Breed 127: 501-506.

Hasan M, Seyis F, Badani AG, et al. 2006. Analysis of genetic diversity in the Brassica napus L. gene pool using SSR markers. Genet Resour Crop Evolut 53(4): 793-802.

Hussain S, Khan WM, Khan MS, et al. 2017. Mutagenic effect of sodium azide $\left(\mathrm{NaN}_{3}\right)$ on $\mathrm{M}_{2}$ generation of Brassica napus $\mathrm{L}$. (variety Dunkled). Pure Appl Biol 6: 226-236.

Javed MA, Siddiqui MA, Khan MKR, et al. 2003. Development of high yielding mutants of Brassica campestris L. cv. Toria selection through gamma rays irradiation. Asian J Plant Sci 2: 192-195.

Khalil SJ, Rehman S, Afridi K, Jan MT. 1986. Damage induced by gamma irradiation in morphological and chemical characteristics of barley. Sarhad J Agric 2: 45-54.

Kharkwal MC. 1998. Induced mutations in chickpea (Cicer arietinum L.). I. Comparative mutagenic effectiveness and efficiency of physical and chemical mutagens. Indian J Genet 58: 159-167.

Kharkwal MC, Pandey RN, Pawar SE. 2004. Mutation breeding for crop improvement. In: Jain HK, Kharkwal MC, eds. Mendelian to 
molecular approaches. New Delhi, India: Narosa Publishing House, pp: 601-645.

Khush GS. 2001. Green revolution: The way forward. Nat Rev Genet 2: 815-822.

Kumar G, Yadav RS. 2010. EMS induced genetic disorders in sesame (Sesamum indirum L.). Rom J Biol Plant Biol 55: 97-104.

Lee YH, Park W, Kim KS, et al. 2018. EMS-induced mutation of an endoplasmic reticulum oleate desaturase gene (FAD2-2) results in elevated oleic acid content in rapeseed (Brassica napus L.). Euphytica 214: 28.

Li T, Yaokui L, Dan Z, et al. 2016. Characteristic and inheritance analysis of targeted mutagenesis mediated by genome editing in rice. Hereditas (Beijing) 38(8): 746-755.

Malek MA, Monshi FI. 2009. Performance evaluation of rapeseed mutants. Bang $J$ Agric Res 36: 81-84.

Meinke DW, Cherry JM, Dean C, Rounsley SD, Koornneef M. 1998. Arabidopsis thaliana: A model plant for genome analysis. Science 282: 679-682.

More UA, Malode SN. 2016. Mutagenic effect of EMS on quantitative characters of Brassica napus $\mathrm{L}$. Cv. Excel in $\mathrm{M}_{1}$ generation. J Global Biosci 5: 4018-4025.

Nabloussi A. 2015. Amélioration génétique du colza: enjeux et réalisations pour un développement durable de la filière. Rabat, Maroc: INRA-DIC Edition. ISBN: 9789954-593-27-1.

Okuzaki A, Ogawa T, Koizuka C, et al. 2018. CRISPR/Cas9mediated genome editing of the fatty acid desaturase 2 gene in Brassica napus. Plant Physiol Biochem 131: 63-69.

Parry MA, Madgwick PJ, Bayon C, et al. 2009. Mutation discovery for crop improvement. J Exp Bot 60: 2817-2825.

Rae AM, Howell EC, Kearsey MJ. 1999. More QTL for flowering time revealed by substitution lines in Brassica oleracea. Heredity 83: 586-596.

Rahman A. 1990. Evolution of improved varieties of rapeseed mustard and sesame through induced mutations. In: Proceedings on "Mutations breeding of oilseed crops" FAO/IAEA, Vienna, Austria, pp. 57-67.

Rahman A, Das ML, Pathan AJ. 1992. New high yielding mutant varieties of mustard (Brassica campestries L, var. Yellow Sarson). J Nucl Agric Biol 21: 281-285.

Rai B, Singh D. 1993. A note on potential sources of dwarfing genes in Indian rapeseed (Brassica campestris L. Prain). Ind J Genet 53: $153-156$.

Roldan-Arjona T, Ariza RR. 2009. Repair and tolerance of oxidative DNA damage in plants. Mutat Res 681: 169-179.

Schnurbush T, Mollers C, Becker HC. 2000. A mutant of B. napus with increased palmitic acid content. Plant Breed 119: 141-144.

Shah SA, Ali I, Rahman K. 1990. Induction and selection of superior genetic variables of oilseed rape (Brassica napus L.). Nucl 27: $37-40$.

Shah SA, Ali I, Iqbal MM, Khattak SU, Rahman K. 1999. Evolution of high yielding and early flowering variety of rapeseed (Brassica napus L.) through in-vivo mutagenesis. In: Proceedings of $3 \mathrm{rd}$
International Symposium New Genetical Approaches to Crop Improvement-III Nuclear Institute of Agriculture, Tandojam, Pakistan, pp. 47-53.

Sharafi Y, Majidi MM, Goli SH, Rashidi F. 2015. Oil content and fatty acids composition in Brassica species. Int J Food Prop 18: 2145 2154.

Siddiqui MA, Khan IA, Khatri A. 2009. Induced quantitative variability by gamma rays and ethylmethane sulphonate alone and in combination in rapeseed (Brassica napus L.). Pak J Bot 41: $1189-1195$.

Singh BD. 2000. Mutations in crop improvement. In: Plant breed. Principles and methods. New Delhi, Kalyani Publishers, pp. 598631.

Solanki IS. 2005. Isolation of macromutations and mutagenic effectiveness and efficiency in lentil (Lens culinaris Medik). Indian J Genet 65: 264-268.

Spasibionek S. 2006. New mutants of winter rapeseed (B. napus L.) with changed fatty acid composition. Plant Breed 125: 259-267.

Sun Q, Lin L, Liu D, et al. 2018. CRISPR/Cas9-mediated multiplex genome editing of the BnWRKY11 and BnWRKY70 genes in Brassica napus L. Int J Mol Sci 19(9): 2716.

Thakur JR, Sethi GS. 1995. Comparative mutagenicity of gamma rays, ethyl methane sulphonate and sodium azide in barley (Hordeum vulgare L.). Crop Res 9: 350-357.

Thurling N, Depittayanan V. 1992. EMS induction of early flowering mutants in spring rape (Brassica napus). Plant Breed 108: 177184.

Tshilenge-Lukanda L, Kalonji-Mbuyi A, Nkongolo KK, Kizungu RV. 2013. Effect of gamma irradiation on morpho-agronomic characteristics of groundnut (Arachis hypogaea L.). Am J Plant Sci 04: 2186-2192.

Van Harten AM. 1998. Mutation breeding, theory and practical applications. Cambridge, United Kingdom: Cambridge University Press, pp. 127-140.

Velasco L, Fernandez-martinez JM, De Haro A. 2008. Inheritance of reduced linolenic acid content in the Ethiopian mustard mutant N2-4961. Plant Breed 127: 263-265.

Wanasundara JPD, Mcintosh TC, Perera SP, Withana-Gamage TS, Mitra P. 2016. Canola/rapeseed protein-functionality and nutrition. OCL 23(4): D407.

Wang Y, Cheng X, Shan Q, et al. 2014. Simultaneous editing of three homoeoalleles in hexaploid bread wheat confers heritable resistance to powdery mildew. Nat Biotechnol 32: 947-951.

Wani AA. 2009. Mutagenic effectiveness and efficiency of gamma rays, ethyl methane sulphonate and their combination treatments in chickpea (Cicer arietinum L.). Asian J Plant Sci 8: 318-321.

Wei C, Zhu L, Wen J, et al. 2018. Morphological, transcriptomics and biochemical characterization of new dwarf mutant of Brassica napus. Plant Sci 270: 97-113.

Zeng X, Zhu L, Chen Y, et al. 2011. Identification, fine mapping and characterization of a dwarf mutant (bnaC. dwf) in Brassica napus. Theor Appl Genet 122(2): 421-428.

Cite this article as: Channaoui S, Labhilili M, Mouhib M, Mazouz H, El Fechtali M, Nabloussi A. 2019. Development and evaluation of diverse promising rapeseed (Brassica napus L.) mutants using physical and chemical mutagens. OCL 26: 35. 